\title{
Renal insulin-like growth factor I and growth hormone receptor binding in experimental diabetes and after unilateral nephrectomy in the rat
}

\author{
S. M. Marshall, A. Flyvbjerg, J. Frystyk, L. Korsgaard and H. Ørskov \\ Institute of Experimental Clinical Research, University of Aarhus, Denmark
}

\begin{abstract}
Summary. We have measured specific binding of insulin-like growth factor I and growth hormone to renal plasma membranes from control, streptozotocin-diabetic, insulin-treated diabetic, uninephrectomised and combined diabetic-uninephrectomised male Wistar rats. Control, insulin-treated and uninephrectomised rats had similar body weights after 7 days $(243 \pm 2 \mathrm{~g})$, whereas diabetic and diabetic-uninephrectomised animals were significantly lighter $(219 \pm 4$ and $203 \pm 4 \mathrm{~g}, p<0.05$ ). Blood glucose concentrations were similar in the diabetic and diabetic-uninephrectomised animals (around $26 \mathrm{mmol} / \mathrm{l}$ ) but significantly lower in the insulintreated group. Right kidney weight increased by $14 \%$ in the control, insulin-treated and sham-nephrectomised animals, by $33 \%$ in the diabetic group, $38 \%$ in the nephrectomised animals and $60 \%$ in the diabetic-nephrectomised group. The renal content of insulin-like growth factor I was similar and stable in the control, insulin-treated and sham-nephrectomised animals ( $208 \pm 14 \mathrm{ng} / \mathrm{g}$ wet weight) but rose to a peak of $669 \pm 35 \mathrm{ng} / \mathrm{g}$ in the diabetic group $(p<0.001)$, $871 \pm 34 \mathrm{ng} / \mathrm{g}$ in the nephrectomised animals $(p<0.001)$ and $1012 \pm 43 \mathrm{ng} / \mathrm{g}$ in the diabetic-uninephrectomised group
\end{abstract}

$(p<0.001)$. Maximum binding of insulin-like growth factor I fell on day 1 in the diabetic group $(8.3 \pm 1.4$ vs $5.2 \pm 0.71 \times$ $\left.10^{-11} \mathrm{~mol} / \mathrm{l} ; p<0.01\right)$ but thereafter was identical to control animals. In the insulin-treated animals, maximum binding rose to $11.0 \pm 1.1 \times 10^{-11} \mathrm{~mol} / \mathrm{l}$, significantly different from control and diabetic animals $(p<0.01)$. Growth hormone binding fell acutely in both the diabetic and diabetic-nephrectomised animals $(3.13 \pm 0.58$ and $2.83 \pm 0.21$ vs $7.77 \pm$ $0.68 \times 10^{-12} \mathrm{~mol} / \mathrm{l} ; p<0.001$ for both). Following uninephrectomy, maximum binding of insulin-like growth factor I and growth hormone was unchanged from control values. We conclude that the rise in renal content of insulin-like growth factor I which precedes the compensatory growth seen after induction of diabetes and uninephrectomy is not due to alterations in insulin-like growth factor I receptor binding and is independent of growth hormone binding.

Key words: Renal hypertrophy, insulin-like growth factor I receptor, growth hormone receptor, experimental diabetes, uninephrectomy.
Renal hypertrophy occurs rapidly after the induction of experimental diabetes and in the remaining kidney following unilateral nephrectomy, a significant increase in kidney weight being seen after 4 days $[1,2]$. Kidney growth is preceded by a rise in the renal content of insulin-like growth factor I (IGF-I) [2-4]. In experimental diabetes, both the increase in IGF-I and the rise in kidney weight are dependent on the severity of the diabetes [5, 6 and both can be prevented by treatment with insulin [2]. In both diabetes and after uninephrectomy, renal growth and the rise in content of IGF-I are prevented by the synthetic somatostatin analogue octreotide [3]. If these two growth stimuli of diabetes plus unilateral nephrectomy are combined, the resultant increase in kidney content of IGF-I and renal weight are additive $[7,8]$.
The source of the renal IGF-I is unclear. Traditionally it has been suggested that IGF-I is synthesised in the liver under the control of growth hormone (GH), and secreted into the circulation to exert its growth promoting effects on distant organs $[9,10]$. However, the demonstration of mRNA for IGF-I [11, 12], in many tissues, including the kidney, suggests that IGF-I may act in a paracrine or autocrine manner. IGF-I mRNA concentrations in the kidney are unchanged for the first 4 days following the induction of experimental diabetes [13]. Following unilateral nephrectomy, IGF-I mRNA levels have been reported as relatively increased [14] or unchanged [15]. Thus, the increased renal IGF-I may not be due to increased local transcription

IGF-I receptors are found in kidney homogenates [16, 17], and on mesangial [18-22] and tubular cells $[21,23]$ in 


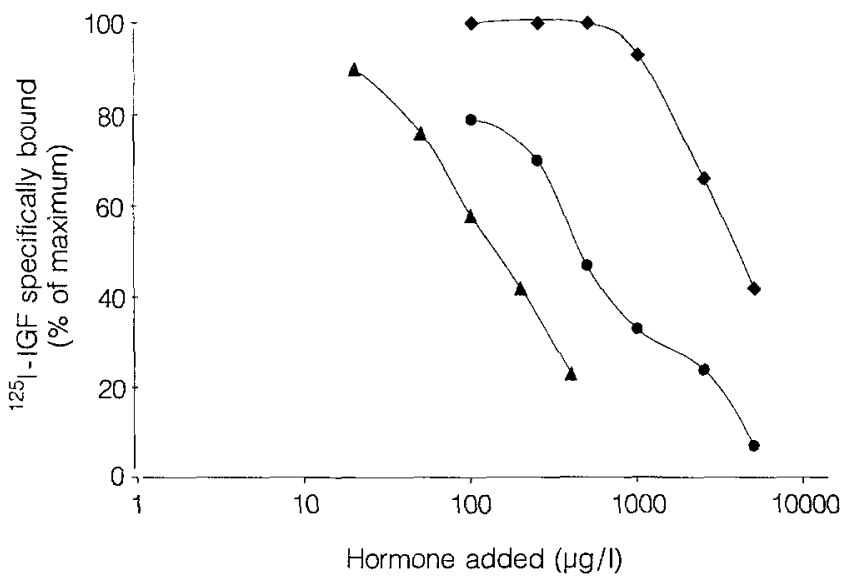

Fig. 1. Competitive inhibition of ${ }^{125}$ I-insulin-like growth factor 1 ( ${ }^{25} \mathrm{I}$-IGF-I) binding to renal membranes by unlabelled insulin-like growth factor I $(\boldsymbol{\Delta})$, insulin-like growth factor II $(\bullet)$ ) and insu$\operatorname{lin}(\bullet \bullet)$

tissue culture. If the increase in IGF-I after diabetes and uninephrectomy is due to increased uptake from the circulation, it might be expected that changes in IGF-I receptor number or affinity might be seen. We have therefore measured specific IGF-I and GH binding to renal plasma membranes after induction of diabetes, uninephrectomy and combined diabetes-uninephrectomy.

\section{Materials and methods}

\section{Animals}

Male Wistar rats (Mollegaards, Avlslab, Eiby, Denmark) of mean body weight $198 \mathrm{~g}$ (range 184-218) were studied. Animals were housed three per cage in a room with $12: 12 \mathrm{~h}$ (06.00-18.00 hours) artificial light cycle, temperature $21 \pm 2{ }^{\circ} \mathrm{C}$ and humidity $55 \pm 2 \%$. The animals had free access to standard rat fodder (Altromin, Lage, FRG) and tap water throughout the experiment. The animals were randomised into six groups matched for body weight: Group 1 control animals $(n=18)$; Group 2 diabetic animals $(n=50)$; Group 3 insulin-treated diabetic animals $(n=16)$; Group 4 uninephrectomised animals $(n=40)$; Group 5 sham uninephrectomised animals $(n=12)$; Group 6 uninephrectomised, diabetic animals $(n=50)$.

Diabetes was induced on day 0 by intravenous injection of streptozotocin ( $55 \mathrm{mg} / \mathrm{kg}$ body weight) in acidic $0.154 \mathrm{~mol} / \mathrm{l} \mathrm{NaCl}, \mathrm{pH} 4.0$, after $12 \mathrm{~h}$ food deprivation. Left nephrectomy was performed via a flank incision. For sham nephrectomy, the left kidney was gently manipulated only. In group 6, streptozotocin was administered immediately following nephrectomy. Eighteen hours after the injection of streptozotocin, and daily thereafter, the animals were weighed, urinalysis was performed for glucose and ketones using Neostix 4 (Ames Limited, Stoke Poges, Slough, Buckinghamshire, UK) and tail-vein blood glucose determined by Haemoglucotest 1-44 and Reflolux Il reflectance meter (Boehringer-Mannheim, Mannheim, FRG). Insulin treatment with long-acting heat-treated bovine Ultralente insulin (Novo, Bagsvaerd, Denmark) was begun $18 \mathrm{~h}$ after the administration of streptozotocin, when all diabetic animals had blood glucose levels $>18 \mathrm{mmol} / 1$. The initial dose of insulin was 4-6 units, followed by 1-2 units daily depending on the blood glucose concentration. Fodder consumption was measured by housing animals from groups $1,2,4$ and 6 in metabolic cages for $24 \mathrm{~h}$ on days $1-2$ and $3-4$.

On days $1,2,3,4$ and 7 , ten animals were killed from the diabetic, uninephrectomised and diabetic-uninephrectomised groups. Six control animals were killed on days 0,2 and 7, and six or eight rats from the sham-nephrectomised and insulin-treated diabetic groups on days 2 and 7 . Under anaesthesia with sodium barbital $(50 \mathrm{mg} / \mathrm{kg})$, blood was drawn from the retroorbital venous plexus and serum stored at $-20^{\circ} \mathrm{C}$ for later determination of IGF-I. Both kidneys were rapidly removed, cleaned, weighed and frozen in liquid nitrogen. The right kidney was used for determination of IGF-I content and the left for hormone binding studies.

\section{Hormone binding studies}

A full sequence IGF-I analogue was obtained from Amgen Biologicals, (Thousand Oaks, Calif., USA) IGF-II from Bachem, (Bubendorf, Switzerland) and GH from Nordisk, (Gentofte, Denmark). Binding of hormones to renal plasma cell membranes was performed by a modification of the method of Marshall et al. [24]. Membranes were prepared by homogenisation of the entire left kidney on ice in $3 \mathrm{mmol} / \mathrm{l}$ imidazole in $300 \mathrm{mmol} / \mathrm{l}$ sucrose, $\mathrm{pH} 8.0$, containing $360 \mathrm{mg} / \mathrm{l}$ PMFS, $4 \mathrm{~g} / \mathrm{l}$ EDTA, 40,000 U/l Trasylol and $100 \mathrm{mg} / \mathrm{l} \mathrm{baci-}$ tracin. Homogenisation was by Ultra Turax homogeniser at $2400 \mathrm{rev} / \mathrm{min}$ for $10 \mathrm{~s}$ on two occasions. The homogenate was centrifuged at $2400 \mathrm{rev} / \mathrm{min}, 4^{\circ} \mathrm{C}$, for $10 \mathrm{~min}$ and the supernatant spun at $33,000 \mathrm{~g}, 4^{\circ} \mathrm{C}$ for $30 \mathrm{~min}$. The pellet was washed once before resuspension in Tris assay buffer, $25 \mathrm{mmol} / \mathrm{l}$, $\mathrm{pH} 8.0$, containing $10 \mathrm{mmol} / \mathrm{l}$ $\mathrm{MgCl}, 100 \mathrm{mg} / \mathrm{l}$ bacitracin and $10 \mathrm{~g} / \mathrm{l}$ bovine albumin. An aliquot was taken for protein determination by the Lowry method [25] and the rest of the homogenate frozen at $-70^{\circ} \mathrm{C}$ until binding was assayed. Binding assays were performed at $4^{\circ} \mathrm{C}$ in Tris assay buffer described above, in Eppendorf tubes. To approximately $25 \mu \mathrm{g}$ (for IGF-I binding) or $50 \mu \mathrm{g}$ (for $\mathrm{GH}$ binding) membrane protein was added increasing concentrations of cold IGF-I (to $800 \mathrm{ng} / \mathrm{ml}$ ) or GH $(400 \mathrm{ng} / \mathrm{ml})$ and approximately $0.07 \mathrm{pmol}$ mono-iodo- ${ }^{125} \mathrm{I}-\mathrm{IGF}-\mathrm{I}$, specific activity $2000 \mathrm{Ci} / \mathrm{mmol}$ (Amersham International, Aylesbury, Buckinghamshire, UK) or approximately $0.05 \mathrm{pmol}$ monoiodo- ${ }^{125} \mathrm{I}-\mathrm{GH}$, specific activity $2000 \mathrm{Ci} / \mathrm{mmol}$ (Nordisk). The reaction was incubated at $4^{\circ} \mathrm{C}$ for $18 \mathrm{~h}$, conditions shown previously to maximise specific binding and minimise degradation of the labelled hormones. After termination of the reaction by the addition of $300 \mu \mathrm{l}$ ice-cold assay buffer, the tubes were centrifuged at $4^{\circ} \mathrm{C}$, $2400 \mathrm{rev} / \mathrm{min}$ for $30 \mathrm{~min}$, the supernatant aspirated and the pellet washed twice with $300 \mu l$ assay buffer. The tips of the centrifuge tubes were cut off and the radioactivity in the pellet counted. Nonspecific binding, defined as the counts of ${ }^{125} \mathrm{I}-\mathrm{IGF}-\mathrm{I}$ or ${ }^{125} \mathrm{I}-\mathrm{GH}$ remaining bound in the presence of $800 \mathrm{ng} / \mathrm{ml} \mathrm{IGF-I} \mathrm{or} 400 \mathrm{ng} / \mathrm{ml} \mathrm{GH}$, was subtracted from the total binding to give specific binding. Scatchard and Hill plot analysis of the binding data was by the EBDA computer programme [26]. Specific binding was corrected to $25 \mu \mathrm{g}$ membrane protein for IGF-I and to $50 \mu \mathrm{g}$ for $\mathrm{GH}$.

Characterisation of the IGF-I receptor was done by assessing the displacement of ${ }^{125}$ I-IGF-I by unlabelled IGF-I, IGF-II and insulin. Half-maximal displacement was $125 \mu \mathrm{g} / \mathrm{l}$ for IGF-I, $595 \mu \mathrm{g} / \mathrm{l}$ for IGFII and $4200 \mu \mathrm{g} / 1$ for insulin (Fig. 1). This characteristic displacement pattern has been reported previously for IGF-I receptors in several tissue preparations, including renal tissue $[17,19,22]$. Degradation of ${ }^{125} \mathrm{I}-\mathrm{IGF}-\mathrm{I}$ and ${ }^{125} \mathrm{I}-\mathrm{GH}$ in the binding assays was assessed as the precipitability by $20 \%$ trichloroacetic acid of aliquots of supernatants from binding assays and was less than $10 \%$.

\section{IGF-I analysis}

Renal tissue was extracted in $1 \mathrm{~mol} / \mathrm{l}$ acetic acid $[6,10]$. After lyophilisation, the samples were redissolved in $40 \mathrm{mmol} / \mathrm{l}$ phosphate buffer, $\mathrm{pH} 8.0$ and stored at $-20^{\circ} \mathrm{C}$ until assay. Serum was extracted in acetic acid-methanol [27]. The IGF-I radioimmunoassay used IGF-I antibody UB286 (raised by LE Underwood and JJ van Wyk, Paediatric Endocrinology, University of North Carolina, Chapel Hill, NC, USA) donated by the US National Hormone and Pituitary Program. 
Table 1. Metabolic and insulin-like growth factor-I (IGF-I) and growth hormone (GH) receptor binding data in control, sham-nephrectomised, insulin-treated, diabetic, uninephrectomised and uninephrectomised-diabetic animals on day 7

\begin{tabular}{|c|c|c|c|c|c|c|}
\hline & Control & Nephrectomised & $\begin{array}{l}\text { Sham nephrec- } \\
\text { tomised }\end{array}$ & Diabetic & Insulin-treated & $\begin{array}{l}\text { Nephrectomised- } \\
\text { diabetic }\end{array}$ \\
\hline $\begin{array}{l}\text { Body weight } \\
\text { (g) }\end{array}$ & $243 \pm 3$ & $230 \pm 5$ & $238 \pm 3$ & $219 \pm 4^{a}$ & $243 \pm 2$ & $203 \pm 4^{a}$ \\
\hline $\begin{array}{l}\text { Blood glucose } \\
(\mathrm{mmol} / \mathrm{l})\end{array}$ & $6.0 \pm 0.3$ & $5.6 \pm 0.4$ & $5.9 \pm 0.3$ & $27.7 \pm 0.2^{c}$ & $9.1 \pm 1.8$ & $28.2 \pm 0.3^{c}$ \\
\hline $\begin{array}{l}\text { Kidney weight } \\
\text { (mg) }\end{array}$ & $849 \pm 18$ & $1040 \pm 24^{b}$ & $782 \pm 24$ & $989 \pm 25^{b}$ & $828 \pm 20$ & $1191 \pm 33^{c}$ \\
\hline $\begin{array}{l}\text { Maximum binding IGF-I } \\
\left(\times 10^{-11} \mathrm{~mol} / \mathrm{l}\right)\end{array}$ & $7.0 \pm 0.8$ & $6.0 \pm 0.5$ & $12.0 \pm 1.1^{\mathrm{b}}$ & $8.0 \pm 0.5$ & $11.0 \pm 1.1^{\mathrm{b}}$ & $7.0 \pm 0.5$ \\
\hline $\begin{array}{l}\text { Affinity constant IGF-I } \\
\left(\times 10^{8} 1 / \mathrm{mol}\right)\end{array}$ & $7.4 \pm 0.5$ & $6.7 \pm 0.3$ & $5.5 \pm 0.5^{\mathrm{a}}$ & $7.4 \pm 0.2$ & $6.1 \pm 0.1^{\mathrm{a}}$ & $7.5 \pm 0.3$ \\
\hline
\end{tabular}

Mean \pm SEM

${ }^{\mathrm{a}} p<0.05,{ }^{\mathrm{b}} p<0.01,{ }^{\mathrm{c}} p<0.001$ vs control
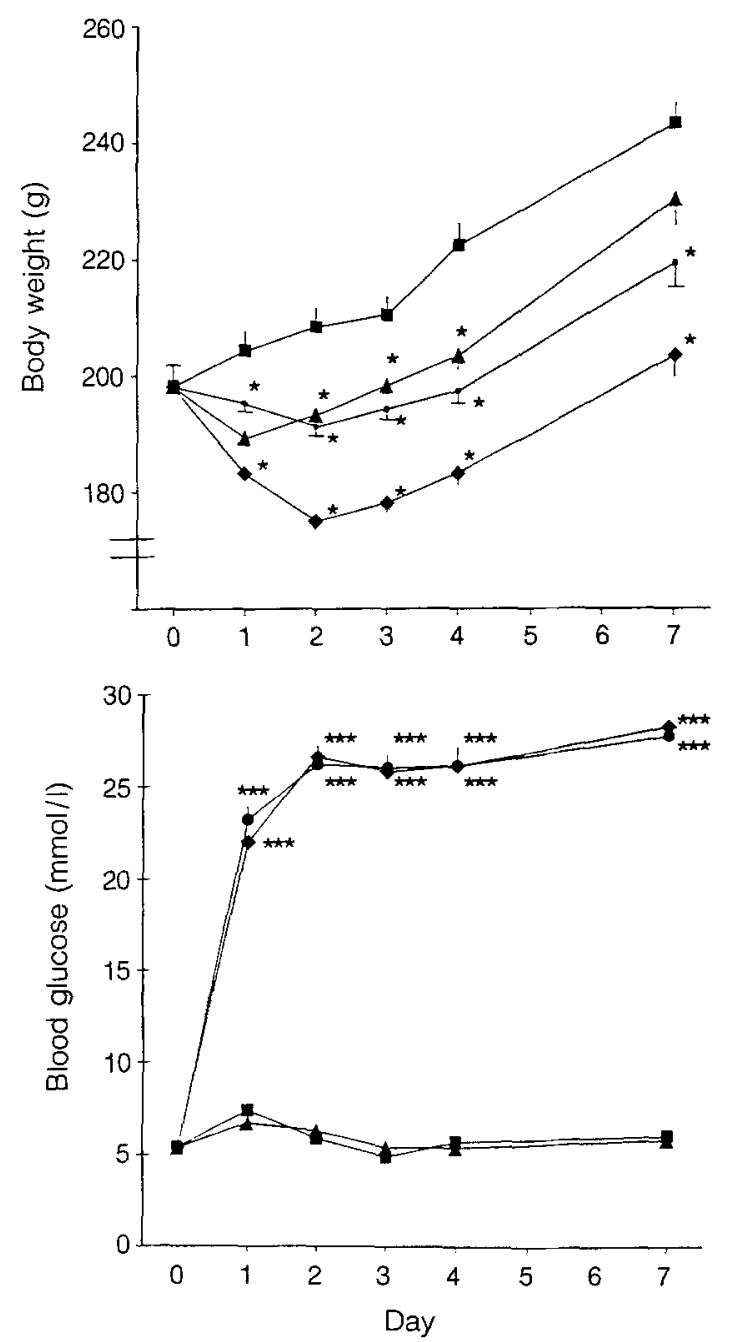

Fig.2. Body weight (upper panel) and blood glucose (lower panel) in control $(-)$ ), diabetic $(-)$, nephrectomised $(\leftarrow)$ and diabetic-nephrectomised animals $(\bullet)$. * $p<0.05, * * * p<0.001$ vs control group

\section{Statistical analysis}

Results are expressed as mean \pm SEM. Differences within and between groups were assessed by analysis of variance with correction for multiple testing, using the Statistical Package for the Social Sciences [28].

\section{Results}

Body weight

Control, insulin-treated and sham-nephrectomised animals gained weight at similar rates during the study (Table 1). In the diabetic group, body weight decreased from $198 \pm 3 \mathrm{~g}$ on day 0 to $191 \pm 1 \mathrm{~g}$ on day $2(p<0.05)$, but thereafter increased to $219 \pm 4 \mathrm{~g}$ on day 7 (Fig. 2). The body weight of the diabetic animals was significantly less than that of the control and insulin-treated animals at all time points from day 1 onwards. Nephrectomised animals initially lost weight, so that on day 2 they were significantly lighter than control and sham-nephrectomised animals (193 \pm 1 vs $208 \pm 3$ and $205 \pm 2 \mathrm{~g}, p<0.05$ for both). However, by day 7 , body weight of the nephrectomised animals was identical to that of control and sham-operated animals. In the diabetic-nephrectomised animals, body weight reached a nadir on day 2 , and at all time-points body weight was significantly less than in the control, diabetic and nephrectomised animals.

\section{Blood glucose}

Eighteen hours after the injection of streptozotocin, blood glucose was identical in the diabetic and insulin-treated animals $(23.2 \pm 0.7$ and $23.5 \pm 0.9 \mathrm{mmol} / 1)$. In the diabetic group, blood glucose remained around $26 \mathrm{mmol} / \mathrm{l}$ for the duration of the experiment (Fig. 2). After initiation of in- 

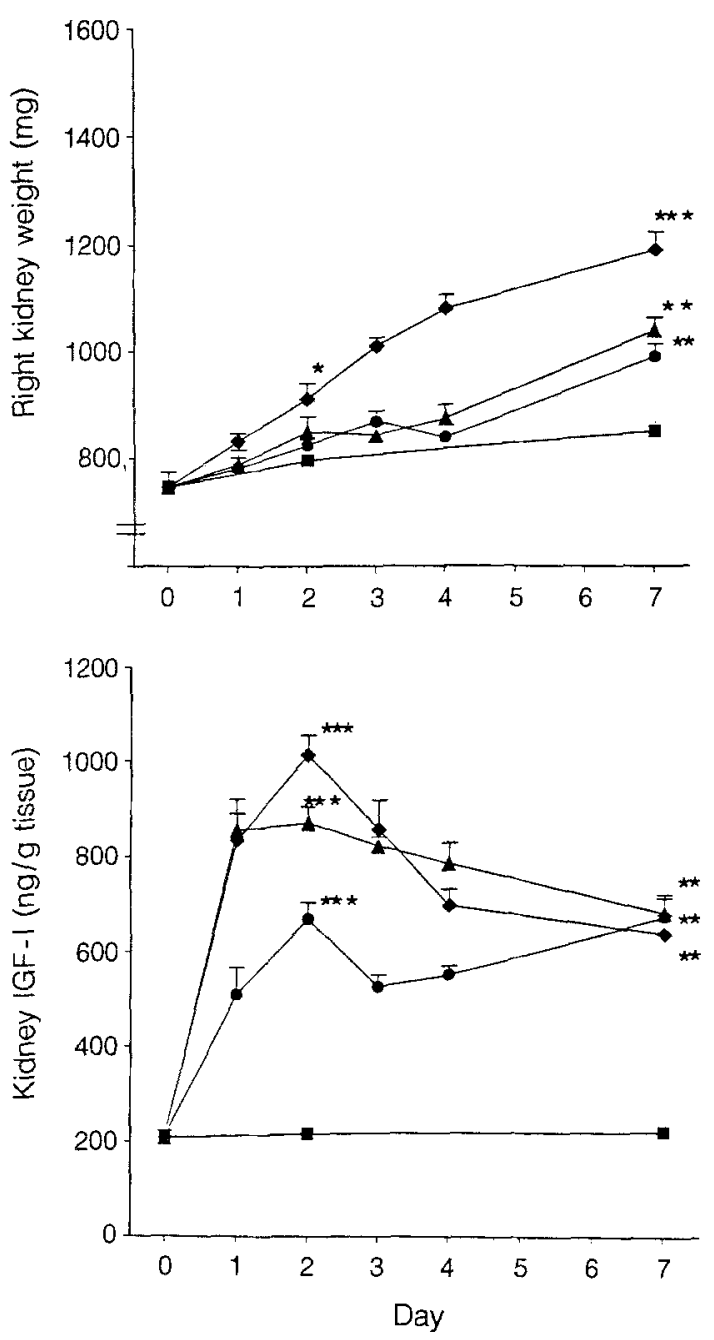

Fig.3. Right kidney weight (upper panel) and kidney content of insulin-like growth factor I (lower panel) in control ( - - ) diabetic $(\bullet)$, nephrectomised $(\backsim)$ ) and diabetic-nephrectomised animals $(\bullet)$. * $p<0.05$, ** $p<0.01, * * * p<0.001$ vs control animals

sulin therapy, blood glucose fell to normal values in the insulin-treated group, only being significantly greater than in the normal animals on day $3(9.2 \pm 1.0$ vs $4.9 \pm 0.2 \mathrm{mmol} / \mathrm{l}, p<0.05)$. In the combined diabetic-nephrectomised animals, blood glucose was identical to that in the diabetic group at all time points.

\section{Right kidney weight}

The right kidney weight increased in a similar manner in control, sham-nephrectomised and insulin-treated diabetic animals, the increase being around $14 \%$ (Table 1). There was a $33 \%$ increase in the wet weight of the right kidney from the diabetic animals over the course of the study (Fig. 3). In the diabetic group, the right kidney weight was significantly different from that in the insulintreated group on day $2(824 \pm 14 \mathrm{mg}$ vs $768 \pm 15 \mathrm{mg}$, $p<0.05)$ and significantly different to that in the insulintreated and control animals on day $7(989 \pm 25$ vs $828 \pm 20$ and $849 \pm 18 \mathrm{mg}, p<0.01$ ). The right kidney weight in the nephrectomised group increased to $1040 \pm 24 \mathrm{mg}$ on day 7 $(p<0.01)$, an increase of $38 \%$, and was significantly heavier than in the sham-nephrectomised and control animals on day $7(1040 \pm 24 \mathrm{mg}$ vs $782 \pm 24 \mathrm{mg}$ and $849 \pm 18 \mathrm{mg}$, $p<0.01$ for both). In the combined diabetic-nephrectomised animals, right kidney weight increased by $60 \%$ to $1191 \pm 33 \mathrm{mg}$ on day $7(p<0.001)$, significantly heavier than kidneys from the diabetic $(989 \pm 25 \mathrm{mg}, p<0.05)$, nephrectomised $(1040 \pm 24 \mathrm{mg}, p<0.05)$ and control animals $(849 \pm 18 \mathrm{mg}, p<0.001)$.

\section{Renal IGF-I content}

The IGF-I content of the right kidney, expressed as ng IGF-I/g wet tissue weight, was $208 \pm 14 \mathrm{ng} / \mathrm{g}$ in the control animals on day 0 and remained similar in the control, insulin-treated and sham-nephrectomised animals throughout. In the diabetic group, the renal content of IGF-I increased to $669 \pm 35 \mathrm{ng} / \mathrm{g}$ on day $2(p<0.001)$, significantly higher than in control $(217 \pm 20 \mathrm{ng} / \mathrm{g} ; p<0.001)$ and insulin-treated animals $(268 \pm 41 \mathrm{ng} / \mathrm{g} ; \quad p<0.01$; Fig. 3). The kidney IGF-I content remained higher in the diabetic group than in control and insulin-treated animals for the duration of the study. Similarly, in the nephrectomised and diabetic-nephrectomised animals, renal content of IGF-I rose to $871 \pm 34 \mathrm{ng} / \mathrm{g}$ and $1012 \pm 43 \mathrm{ng} / \mathrm{g}$ respectively on day $2(p<0.001$ for both) and remained elevated above control, insulin-treated and sham-nephrectomised animals throughout. In the diabetic-nephrectomised animals, the kidney content of IGF-I on day 2 was significantly greater than in the diabetic and nephrectomised animals ( $p<0.05$ for both).

\section{Serum IGF-I}

Serum IGF-I was $1023 \pm 53 \mathrm{mg} / \mathrm{l}$ in the control group on day 0 and was similar in all groups at all time points throughout the study.

\section{IGF-I binding}

In all groups of animals, analysis of the binding of IGF-I revealed linear Scatchard and Hill plots, with Hill coefficient 0.99 , suggesting one class of receptors and non-cooperativity (Fig.4). Maximal binding to renal plasma membranes $\left(B_{\max }\right)$ was $8.2 \pm 1.4 \times 10^{-11} \mathrm{~mol} / \mathrm{l}$ per $25 \mu \mathrm{g}$ membrane protein on day 0 in the control animals and remained constant throughout (Fig. 5). $B_{\max }$ decreased from the baseline value in the diabetic group to $5.2 \pm 0.7 \times 10^{-11}$ $\mathrm{mol} / 1$ per $25 \mu \mathrm{g}$ membrane protein on day $1(p<0.01)$ but thereafter was similar to values in the control group. In the insulin-treated animals, $B_{\max }$ increased to $11.0 \pm 1.1 \times 10^{-11} \mathrm{~mol} / \mathrm{l}$ per $25 \mu \mathrm{g}$ membrane protein on day 7, compared to $7.0 \pm 0.8$ in the control group $(p<0.01)$ and $8.0 \pm 0.5$ in the diabetic group $(p<0.01)$. $B_{\max }$ in the nephrectomised animals was identical to the control and diabetic animals throughout. In the shamoperated animals, $B_{\text {max }}$ rose, so that on day 7 it was significantly higher than in control and nephrectomised animals $\left(12.0 \pm 1.1\right.$ vs $7.0 \pm 0.8$ and $6.0 \pm 0.5 \times 10^{-11} \mathrm{~mol} / \mathrm{l}$ per $25 \mu \mathrm{g}$ 

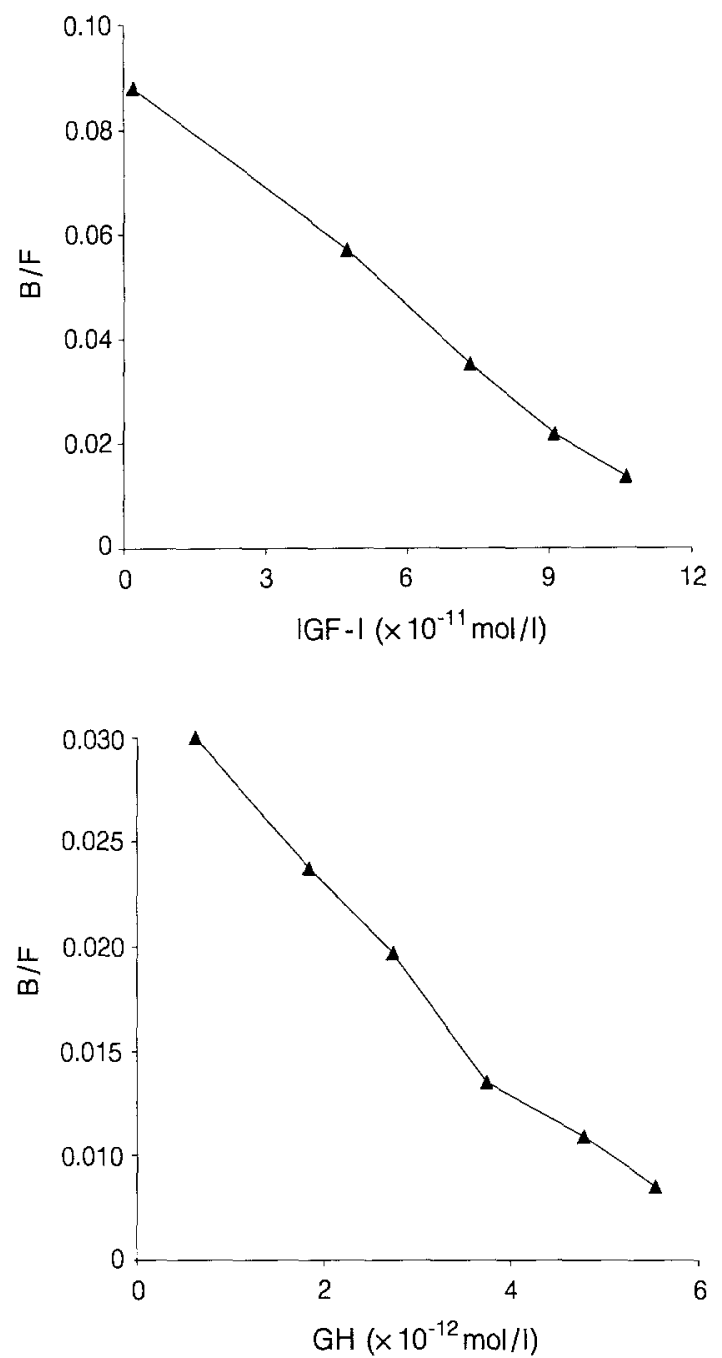

Fig. 4. Scatchard analysis of ${ }^{125} \mathrm{I}$-insulin-like growth factor I $\left({ }^{125} \mathrm{I}\right.$ IGF-I) (upper panel) and ${ }^{125} \mathrm{I}$-growth hormone $\left({ }^{125} \mathrm{I}-\mathrm{GH}\right)$ (lower panel) binding to kidney membranes. B/F: ratio of bound to free ${ }^{125} \mathrm{I}$-insulin-like growth factor I or growth hormone

membrane protein $(p<0.01)$. $\mathrm{B}_{\max }$ in the combined diabetic-nephrectomised animals was identical to control, diabetic and nephrectomised animals during the study.

Affinity constant $\left(\mathrm{K}_{\text {aff }}\right)$ was $7.8 \pm 0.3 \times 10^{8} \mathrm{l} / \mathrm{mol}$ in the control group on day 0 and was unchanged in the control, nephrectomised, diabetic and combined diabetic-nephrectomised animals for the 7 days. In addition, the affinity constant of $7.79 \times 10^{8} 1 / \mathrm{mol}$ reported here is very similar to previously reported values [19,21-23], suggesting that the specific IGF-I binding measured here is similar to that on which others have reported. In the insulintreated group, $\mathrm{K}_{\mathrm{aff}}$ decreased to $6.1 \pm 0.1 \times 10^{8} \mathrm{l} / \mathrm{mol}$ on day 7 and to $5.5 \pm 0.5$ in the sham-nephrectomised animals $(p<0.05$ for both groups vs control and nephrectomised animals).

\section{GH binding}

As with IGF-I binding, GH binding kinetics showed linear Scatchard and Hill plots, with Hill coefficient of 1 , suggesting one class of receptor and non-cooperativity of
S.M. Marshall et al.: Renal IGF-I and GH binding during renal growth
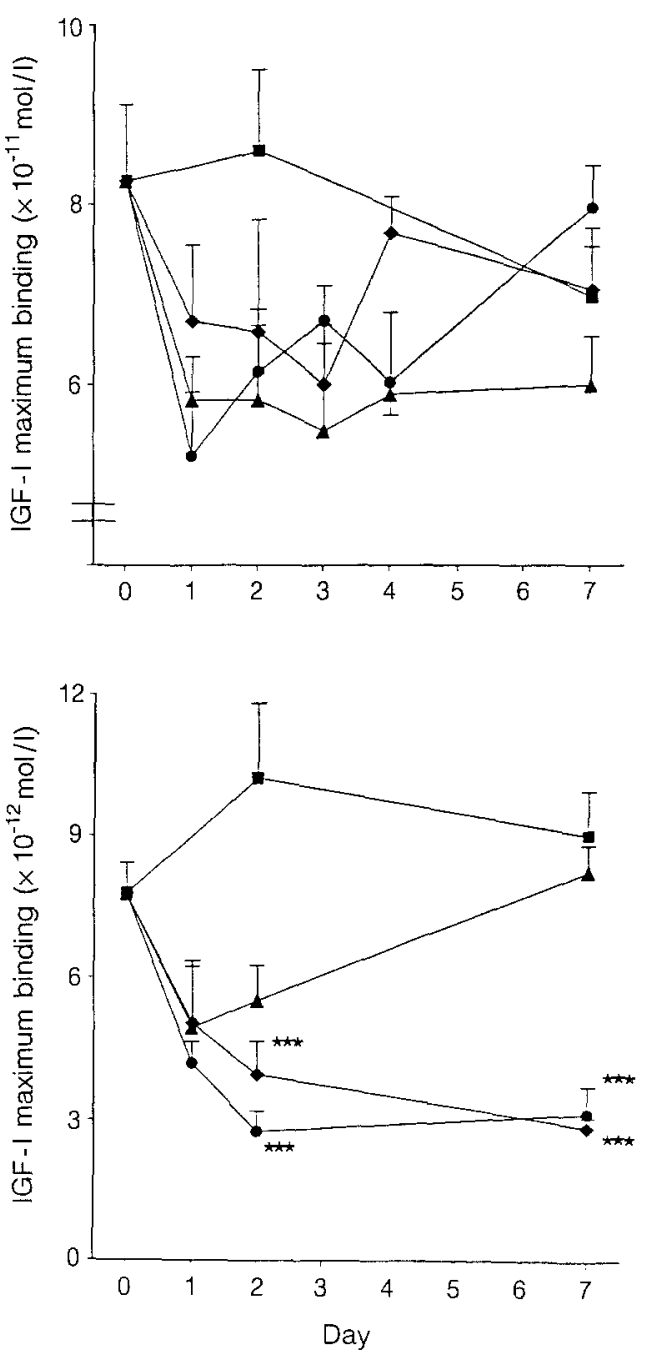

Fig.5. Maximal binding of ${ }^{125} \mathrm{I}$-insulin-like growth factor I ( ${ }^{125} \mathrm{I}-\mathrm{IGF}$ I) (upper panel) and ${ }^{125} \mathrm{I}$-growth hormone ( $\left.{ }^{175} \mathrm{I}-\mathrm{GH}\right)$ (lower panel) to

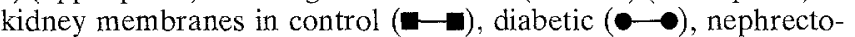
mised $(\bullet-\mathbf{A})$ and diabetic-nephrectomised animals $(\bullet)$ ). **** $p<0.001$ vs control animals

binding (Fig. 4). $\mathrm{B}_{\max }$ was $7.8 \pm 0.7 \times 10^{-12} \mathrm{~mol} / \mathrm{l}$ per $50 \mu \mathrm{g}$ membrane protein on day 0 in the control animals and remained similar in control, sham-nephrectomised, nephrectomised and insulin-treated animals for the duration of the experiment (Fig. 5). In the diabetic and combined diabetic-nephrectomised animals, $B_{\max }$ fell to $3.1 \pm 0.6$ and $2.8 \pm 0.2 \times 10^{-12} \mathrm{~mol} / \mathrm{l}$ per $50 \mu \mathrm{g}$ membrane protein on day 7 ( $p<0.001$ compared to control, insulintreated and nephrectomised animals). Affinity constant was $4.4 \pm 0.3 \times 10^{9} \mathrm{l} / \mathrm{mol}$ in the control group on day 0 and remained similar in all groups throughout the experiment.

\section{Fodder consumption}

In the diabetic, nephrectomised and diabetic-nephrectomised animals, fodder consumption on day 1-2 was less than that of the control animals ( $p<0.05$ for all; Fig. 6). However, by day $3-4$, consumption had returned to that seen in the control animals in all three experimental groups. 


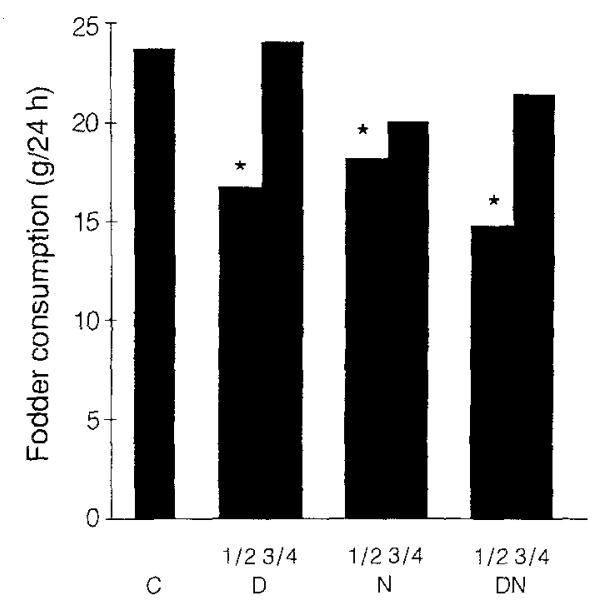

Fig.6. Fodder consumption in control (C), diabetic (D), nephrectomised $(\mathrm{N})$ and diabetic-nephrectomised $(\mathrm{DN})$ animals on days $1-2$ $(1 / 2), 2-3(2 / 3)$ or $3-4(3 / 4)$. * $p<0.05$ vs control animals

\section{Discussion}

We have shown similar IGF-I binding to renal plasma membranes in diabetic, uninephrectomised, uninephrectomised-diabetic and control animals, simultaneously with an acute and sustained rise in the renal content of IGF-I in the experimental animals only. The lack of prolonged change in the binding data suggests that this rise in the renal content of IGF-I is not due to increased uptake of IGF-I by renal cells, either from the systemic or local circulation or from urine. Our results contrast with a recent study reporting an increase in IGF-I binding to similar renal membrane preparations 14 days after induction of streptozotocin diabetes, with an increase in the IGF-I receptor mRNA levels [29]. However, the IGF-I content of the kidney homogenates was decreased and the IGF-I peptide mRNA levels unchanged. Taken together, these studies suggest that IGF-I binding to renal cells after induction of diabetes is time-dependent. In the initial phase, the IGF-I content is increased and binding unchanged. Later, as the IGF-I content falls, synthesis of the receptor and receptor binding are increased, perhaps as a second ary phenomenon.

The transient decline in maximum specific binding in the diabetic group $24 \mathrm{~h}$ after injection of streptozotocin may be related to acute hypoinsulinaemia. Conversely, in the insulin-treated animals, there was a rise in the maximum specific binding and a fall in the affinity constant. It is likely that the insulin-treated animals were hyperinsulinaemic and that this was the cause of the changes in IGF-I binding. Insulin is known to regulate IGF-I binding. In human mesangial cells grown in tissue culture, addition of $10-100 \mathrm{ng} / \mathrm{ml}$ insulin to the culture medium resulted in enhancement of specific IGF-I binding [22]. Alternatively, hyperinsulinaemia will lower the serum levels of IGFbinding protein I, perhaps making more IGF-I available for cellular uptake and increasing the maximum binding [30].

There was a pronounced and sustained reduction in the specific binding of $\mathrm{GH}$ in the untreated diabetic and combined uninephrectomy-diabetic groups, with no change in the affinity constant. Binding in the insulin-treated and uninephrectomised groups was similar to that in control animals throughout. These data suggest that the rise in the renal content of IGF-I in the experimental animals is not under growth hormone control. It has been suggested that the effects of GH on renal function are mediated by IGF-I, but changes in functional parameters appear to occur independently to changes in renal size [31]. Recently, it has been reported that concentrations of the mRNA for the GH receptor are unchanged in kidney and liver in diabetes [32]. Thus the decline in maximum specific binding of $\mathrm{GH}$ in the diabetic animals may be due to internalisation of the GH receptor or alterations in recycling, rather than to decreased synthesis. An alternative explanation for the renal $\mathrm{GH}$ binding changes reported here is downregulation secondary to changes in serum $\mathrm{GH}$ concentrations. Mean serum growth hormone concentrations fall rapidly in streptozotocin diabetes, with loss of the secretory pulses [33]. The similar decline in maximum $\mathrm{GH}$ binding in the combined uninephrectomy-diabetic group but not in the uninephrectomy group supports the concept that changes in GH binding are secondary to the metabolic consequences of diabetes.

It is unclear why the maximum specific binding and affinity constant for IGF-I changed in the sham-nephrectomised animals. The sham and uninephrectomised animals were handled in an identical manner peri-operatively. It may be that the stress-induced rise in hormones such as glucagon and cortisol enhances IGF-I binding in the sham nephrectomised animals, whilst in the uninephrectomised animals this rise is counterbalanced by a fall in binding due solely to the removal of one kidney.

The lack of change in the IGF-I binding parameters in all three experimental groups suggests that in each situation, the rise in the renal content of IGF-I is not related to changes in the IGF-I receptor. This is in keeping with the concept that the increase in the renal content of IGF-I cannot be accounted for by increased cellular uptake, either from the systemic or local circulation or from urine. An alternative explanation is for an increased local synthesis of IGF-I. We have recently demonstrated in an identical model, that IGF-I mRNA levels in the kidney do not change for the first 4 days of experimental diabetes [13]. Thus, alternative mechanisms such as an alteration in the mRNA steady-state or altered post-transcriptional processing may account for the rise in the IGF-I. The mechanisms accounting for the increased renal content of IGF-I may not be similar in diabetes and after uninephrectomy. Fagin and Melmed have recently reported a relative increase in IGF-I mRNA in the remaining kidney after unilateral nephrectomy [14]. However, using a more specific and sensitive solution hybridisation assay, another group have not shown any change in IGF-I mRNA levels after unilateral nephrectomy [15]. Thus, it is not clear whether the rise in the renal content of IGF-I after uninephrectomy may be accounted for by increased local synthesis.

Although IGF-I receptors have been found on many cell types of the kidney [19-22], the changes in IGF-I content seen during renal growth may be localised to specific areas of the nephron. In the normal rat kidney, IGF-I has 
been shown by immunohistochemical staining to be confined to the cells of the medullary collecting duct and those parts of the thin loop of Henle in the outer medulla [15, 34-36]. After unilateral nephrectomy, positive staining is seen in the remaining kidney in all parts of the collecting ducts and the thin loop of Henle [15, 34]. It may be that by studying homogenates of whole kidneys, small but very important changes in IGF-I synthesis or uptake in very precisely localised areas of the nephron are not detected. Further studies should perhaps examine specific areas of the nephron separately. In human diabetic nephropathy, expansion of the mesangium is thought to be important in the decline of renal function [37]. The role of IGF-I in mesangial growth is thus also of interest.

In summary, we have shown no change in specific binding of IGF-I to renal plasma membranes after induction of diabetes or uninephrectomy, suggesting that the rise in the renal content of IGF-I seen in both these situations is not due to increased uptake of IGF-I from the circulation. Specific binding of $\mathrm{GH}$ fell in the diabetic group, probably secondary to the declining serum $\mathrm{GH}$ concentrations.

Acknowledgements. SMM held a British Medical Research Council Travelling Fellowship. We are grateful to Drs L. E. Underwood and J.J. van Wyk of the National Hormone and Pituitary Program for the gift of the IGF-I antiserum. Ms. K. Nyborg gave skillful technical help. The study was supported by the Danish Diabetes Association, the Danish Medical Research Council, the Ruth König Petersen Foundation and the Novo Foundation.

\section{References}

1. Seyer-Hansen K (1976) Renal hypertrophy in streptozotocindiabetic rats. Clin Sci 51:551-554

2. Flyvbjerg A, Thorlacius-Ussing O, Næraa R, Ingerslev J, Ørskov $\mathrm{H}$ (1988) Kidney tissue somatomedin $\mathrm{C}$ and initial renal growth in diabetic and uninephrectomised rats. Diabetologia $31: 310$ 314

3. Flyvbjerg A, Frystyk J, Thorlacius-Ussing O, Ørskov H (1989) Somatostatin analogue administration prevents increase in kidney somatomedin $\mathrm{C}$ and initial renal growth in diabetic and uninephrectomised rats. Diabetologia 32: 261-265

4. Stiles AD, Sosenko IRS, D'Ercole AI, Smith BT (1985) Relation of kidney tissue somatomedin-C/Insulin-like growth factor I to postnephrectomy renal growth in the rat. Endocrinology 117 : 2397-2401

5. Seyer-Hansen K (1977) Renal hypertrophy in experimental diabetes: relation to severity of diabetes. Diabetologia $13: 141-$ 143

6. Flyvbjerg A, Ørskov H (1990) Kidney tissue insulin-like growth factor I and initial renal growth in diabetic rats: relation to severity of diabetes. Acta Endocrinol (Copenh) 122:374-378

7. Seyer-Hansen K (1978) Renal hypertrophy in experimental diabetes: A comparison to compensatory hypertrophy. Diabetologia 14: 325-328

8. Flyvbjerg A, Frystyk J, Marshall SM (1990) Additive increase in kidney insulin-like growth factor I and initial renal enlargement in uninephrectomised-diabetic rats. Horm Metabol Res 22:516520

9. Daughaday WH, Hall K, Raben MS, Saimon WD Jn, Van den Brande JL, Van Wyk JJ (1972) Somatomedin: proposed designation for sulfation factor. Nature (London) 235: 107
10. D'Ercole AJ, Stiles AD, Underwood LE (1984) Tissue concentrations of somatomedin $\mathrm{C}$ : further evidence for multiple sites of synthesis and paracrine or autocrine mechanisms of action. Proc Natl Acad Sci 81: 935-939

11. Murphy LJ, Bell GI, Friesen HG (1987) Tissue distribution of insulin-like growth factor I and II messenger ribonucleic acid in the adult rat. Endocrinology 120: 1279-1282

12. Roberts CT Jr, Lasky SR, Lowe WL Jn, Seaman WT, LeRoith D (1987) Molecular cloning of rat insulin-like growth factor I complementary deoxyribonucleic acids: differential messenger ribonucleic acid processing and regulation by growth hormone in extrahepatic tissues. Mol Endocrinol 1: 243-248

13. Flyvbjerg A, Bornfeldt K, Marshall SM, Arnqvist H, Ørskov H (1990) Kidney IGF-I mRNA in initial renal hypertrophy in experimental diabetes in rats. Diabetologia 33: 334-338

14. Fagin JA, Melmed S (1987) Relative increase in insulin-like growth factor I messenger ribonucleic acid levels in compensatory renal hypertrophy. Endocrinology 120: 718-724

15. Lajara R, Rotwein R, Bortz JD et al. (1989) Dual regulation of insulin-like growth factor I expression during renal hypertrophy. Am J Physiol 257: F252-F261

16. Polychronakos C, Guyda JH, Posner BI (1985) Increase in the type 2 insulin-like growth factor receptors in the rat kidney during compensatory growth. Biochem Biophys Res Commun 132: $418-423$

17. Bhaumick B, Bala RM (1987) Binding and degradation of insulin-like growth factors I and II by rat kidney membrane. Endocrinology 120: 1439-1448

18. Abrass CK, Raugi GJ, Gabourel LS, Lovett DH (1988) Insulin and insulin-like growth factor I binding to cultured rat glomerular mesangial cells. Endocrinology 123: 2432-2439

19. Arnquist HJ, Ballermann BJ, King GL (1988) Receptor for and effects of insulin and IGF-I in rat glomerular mesangial cells. Am J Physiol 254: C411-416

20. Conti FG, Striker LJ, Lesniak MA, MacKay K, Roth J, Striker GE (1988) Studies on binding and mitogenic effect of insulin and insulin-like growth factor I in glomerular mesangial cells. Endocrinology 122: 2788-2795

21. Pillion DJ, Haskell JF, Meezan E (1988) Distinct receptors for insulin-like growth factor I in rat renal glomeruli and tubules. Am J Physiol 255: E504-512

22. Aron DC, Rosenzweig JL, Abboud HE (1989) Synthesis and binding of insulin-like growth factor I by human glomerular mesangial cells. J Clin Endocrinol Metab 68: 585-591

23. Hammerman MR, Rogers S (1987) Distribution of IGF receptors in the plasma membrane of proximal tubular celis. Am J Physiol 253: F841-F847

24. Marshall RN, Underwood LE, Voina SJ, Foushee DB, Van Wyk JJ (1974) Characterization of the insulin and somatomedin-C receptors in human placental cell membranes. J Clin Endocrinol Metab 39: 283-292

25. Lowry OH, Osebrough NI, Fara AC, Randall RI (1951) Protein measurements with the folin phenol reagents. J Biol Chem 193: $165-175$

26. McPherson GA (1983) A practical computer-based approach to the analysis of radioligand binding experiments. Comput Programs Biomed 17: 107-114

27. Thorlacius-Ussing O, Flyvbjerg A, Jorgensen KD, Ørskov $\mathrm{H}$ (1988) Growth hormone restores normal growth in selenium treated rats without increase in circulating SMC. Acta Endocrinol (Copenh) 117: 65-72

28. Statistical package for the Social Sciences, SPSS Inc, Chicago, USA 1986

29. Wemer H, Shen-Orr Z, Stannard B, Burguera B, Roberts CT, LeRoith D (1990) Experimental diabetes increases insulin-like growth factor I and II receptor concentration and gene expression in the kidney. Diabetes 39: 1490-1497

30. Suikkari A-M, Koivisto VA, Rutanen E-M, Yki-Jarvinen H, Karonen S-C, Seppala M (1988) Insulin regulates the serum levels of low molecular weight insulin-like growth factor-binding proteins. J Clin Endocrinol Metab 66: 266-272 
31. Hirschberg R, Kopple JD (1989) Effects of growth hormone and IGF-I on renal function. Kidney Int 36 [Suppl 27]: S20-S26

32. Bornfeldt KE, Arnqvist HJ, Enberg B, Mathews LS, Norstedt G (1989) Regulation of insulin-like growth factor-I and growth hormone receptor gene expression by diabetes and nutritional state in rat tissues. J Endocrinol 122: 651-656

33. Tannenbaum GS (1981) Growth hormone secretory dynamics in streptozotocin diabetes: evidence of a role for endogenous circulating somatostatin. Endocrinology 108: 76-82

34. Andersson GL, Skottner A, Jennische E (1988) Immunocytochemical and biochemical localization of insulin-like growth factor $I$ in the kidney of rats before and after uninephrectomy. Acta Endocrinol (Copenh) 119:555-560

35. Hansson HA, Nilsson A, Isgaard J et al. (1988) Immunohistochemical localisation of insulin-like growth factor I in the adult rat. Histochemistry 89: 403-410
36. Bortz JD, Rotwein P, DeVol D, Bechtel PJ, Hansen VA, Hammerman R (1988) Focal expression of insulin-like growth factor I in the rat kidney collecting duct. J Cell Biol 107: 811-817

37. Mauer SM, Steffes MW, Ellis EN, Sutherland DER, Brown DM, Goetz FC (1984) Structural-functional relationships in diabetic nephropathy. J Clin Invest 74: 1143-1155

Received: 8 February 1991

and in revised form: 3 June 1991

Dr. S.M. Marshall

Department of Medicine

The Medical School

Framlington Place

Newcastle upon Tyne NE2 4HH

UK 